POETRY

\title{
From Dover Raceway to Morgan's Harbour
}

\author{
Makesha Evans \\ International University of the Caribbean, JM \\ makesha.evans@gmail.com
}

This collection consists of three poems. Two of these poems provide snapshots of experiences that are rooted in the Jamaican context. "At Dover Raceway" captures the gathering of racing fans who hail from varying socioeconomic strata across the country, and the unifying excitement that accompanies the races. "I Want to Scull" is about a relatively atypical experience in Jamaica a sculling team that met for training at Morgan's Harbour. As with other such endeavors, the club became defunct when no funding could be found to repair the sculls or purchase new ones. In contrast, "Becoming Wisdom" is about a journey from a place of brokenness to one of healing and growth.

Keywords: Dover Raceway; Morgan's Harbour; Jamaica

\author{
At Dover Raceway \\ The sign and then the marl \\ part of a procession \\ witnessed on either side \\ by chariots \\ not allowed to race, \\ mere conveyors \\ of the throng converging. \\ A pass and then to the overpass \\ bodies in concert \\ seekers homing in on the \\ viewing point of choice \\ trackside, dutchie in hand \\ or status lounge \\ food and drink unlimited \\ settling for the start. \\ The music then the voice \\ deejay and commentator in tango \\ rhythm and dance \\ news stream and humour \\ sponsors' names spouting and branding \\ in the in-between \\ until the cars line up \\ names and stats arcing through the buzz \\ excitement gathering like congregants \\ for worship. \\ The flag and then the charge \\ black and white blurred \\ against the whiz of passing colour
}


total engine red unbeatable

blue and yellow gore challenging

Chen in white

coming back to win

Chen in black: emergent victor

drifting to applause

'til it starts again

with breaths bated, scanning eyes

roars and moans

chased with vodka, rum, and turbo.

\section{Want to Scull}

I want to scull

but the boats are broken

and there is no money

to make them whole again.

They lie face down on racks paint work flaky like sunburnt skin, cobwebs and dust

clothing them unchecked

in a cage by Morgan's Harbour.

I see them there each time I pass

pulling off the road to stand

as though visiting a gravestone;

remembering

the sleek grace with which they lived

on Saturday mornings before dawn

slicing through the seas

that touch Port Royal

eight sculls pulling, flipping, and rising

in tandem

and that spill that we took

by the mangroves

limbs treading water while bailing water

until we could climb back in,

row back to a pebbly shore,

and smile ruefully

at our waiting coach.

Each time I drive towards the Palisadoes

I remember how much

I want to scull

to feel the waking sun

draw sweat from my arms

as we pull those sculls in tandem

through the seas that touch Port Royal

gulls watching overhead

and a manatee from below.

\section{Becoming Wisdom}

I.

I once loved a man named Broken

who lived with his family of fears

in a granite house 
feeding on bitter roots

seasoned with rage.

He drew me in with songs of pain.

I held him to my bosom.

His head was too heavy.

I touched his amber skin.

It singed my fingers.

I kissed the tears from his face.

They poisoned me.

I smiled to disarm him.

He pierced me with his sword.

II.

So I ran to the caves

that are lapped by the sea

and watched my blood seep out

to tinge the water.

I had gone to give.

I had meant to heal

and was almost consumed

I, now, the Woman called Wounded.

But my heart still beats.

Hope becomes my restorer.

Sister Love comforts me

and Insight alights on my shoulder.

My wounds turn to scars

and I rise again,

re-christened the Woman called Wisdom.

III.

I cannot save Broken

though I yearn for him.

I now have awoken

to the truth re: him.

My scars are the token

of my love for him.

In words left unspoken

I have died to him.

\section{Competing Interests}

The author has no competing interests to declare.

How to cite this article: Evans, M 2019 From Dover Raceway to Morgan's Harbour. Anthurium, 15(1): 7, 1-3.

Published: 12 February 2019

Copyright: (c) 2019 The Author(s). This is an open-access article distributed under the terms of the Creative Commons Attribution 4.0 International License (CC-BY 4.0), which permits unrestricted use, distribution, and reproduction in any medium, provided the original author and source are credited. See http://creativecommons.org/licenses/by/4.0/. 